\title{
Reactive Oxygen Species Acts as an Important Inducer in Low-temperature-induced Anthocyanin Biosynthesis in Begonia semperflorens
}

\author{
Ying $\mathbf{Q u}{ }^{1}$ and Xue Bai ${ }^{1}$ \\ College of Forestry, Henan Agricultural University, 63 Nongye Road, 450002 Zhengzhou, China \\ Yajun Zhu \\ Henan Academy of Forestry, 4 Linke Road, 450003 Zhengzhou, China \\ Rui Qi, Geng Tian, Yang Wang, Yonghua Li, and Kaiming Zhang ${ }^{2}$
College of Forestry, Henan Agricultural University, 63 Nongye Road, 450002 Zhengzhou, China
}

Additional INDEX words. $\mathrm{H}_{2} \mathrm{O}_{2}$, superoxide anions, AsA-GSH cycle, low temperature, anthocyanin

\begin{abstract}
Leaves of Begonia semperflorens accumulate anthocyanins and turn red under low temperature (LT). In the present work, LT increased $\mathrm{H}_{2} \mathrm{O}_{2}$ content and superoxide anions production rate, causing significant increases in the activities of enzymes and contents of reduced components involved in the ascorbate-glutathione cycle (AsA-GSH cycle). As a result, LT-exposed seedlings increased the expression of genes involved in anthocyanin biosynthesis, and accumulated anthocyanin. Based on LT condition, application of N,N'-dimethylthiourea (DMTU) decreased reactive oxygen species (ROS) content, and unbalanced the AsA-GSH-controlled redox homeostasis. As a result, seedlings in the LT + DMTU group did not accumulate anthocyanin. Our results suggest that ROS may act as an important inducer in LT-induced anthocyanin biosynthesis.
\end{abstract}

As a major class of pigments in plant tissues, anthocyanins are considered stress indicators because their biosynthesis can be induced by many environmental factors, in which low temperature (LT) is a nonignorable inducer (Lo Piero, 2015; Zhang et al., 2015a).

Low temperature generally increases the expression of genes involved in anthocyanin synthesis. Anthocyanin biosynthesis involves the coordinated expression of transcription factors (TFs) and structural genes (Dixon and Steele, 1999; Takos et al., 2006) and the up-regulation of these genes results in anthocyanin accumulation. Both early $\left(C H S, C H I, F 3 H\right.$, and $\left.F 3^{\prime} H\right)$ and late $(D F R, U F G T$, and $A N S$ ) anthocyanin biosynthesis genes are up-regulated in response to LT in many plants (Lo Piero, 2015; Zhang et al., 2011). LT-responsive regulatory elements have been found in the promoter regions of the Vitis vinifera genes $V v C H S 2, V v P A L$, and $V v F 3 H$ (Zhang et al., 2015b). Some TFs have also been suggested to participate in LT-induced anthocyanin accumulation. For example, $H Y 5$ and $H Y H$ were found to be necessary regulators for LT-induced anthocyanin accumulation in Arabidopsis thaliana (Gu et al., 2015). The transcript abundance of MYBA1-1 and MYB5-1 was up-regulated by LT to induce specific anthocyanin biosynthesis genes such as ANS1, ANS2, DFG1, DFR2, and UFGT2 in Actinidia chinensis (Li et al., 2017). High ambient temperature induces degradation of the HY5 protein in a COP1-activity-dependent manner to repress anthocyanin biosynthesis in $A$. thaliana (Kim et al., 2017).

Received for publication 9 July 2018. Accepted for publication 4 Sept. 2018. This research was supported by the Natural Science Foundation of Henan Province (Grant No. 182300410091) and the Key Scientific Research Project of High Education in Henan Province (Grant No. 18B220004).

We are grateful to the three anonymous reviewers for their constructive comments and suggestions.

${ }^{1}$ These authors contributed equally to this work.

${ }^{2}$ Corresponding author. E-mail: K.M.Zhang@henau.edu.cn.
The metabolism of carbohydrates, proteins, and lipids in plants is altered by LT to facilitate cold acclimation. LT impairs photosynthesis and causes a limitation in carbon sink for growth reduction (Wingler, 2015). The consequent excess carbon serves as a substrate for anthocyanin biosynthesis (Hughes et al., 2005; Steyn et al., 2002; Zhang et al., 2013). The imbalance between carbon assimilation and light energy produces relative excess excitation energy, which is thought to be the main driving force for anthocyanin induction under LT conditions (Das et al., 2014; Steyn et al., 2002; Zhu et al., 2016).

Both LT and relative excess excitation energy result in generation of reactive oxygen species (ROS), such as hydroxyl radicals $(\cdot \mathrm{OH})$, superoxide anions $\left(\mathrm{O}_{2}{ }^{--}\right)$, and hydrogen peroxide. Although well known for the damage they cause to cells, ROS are considered signalling molecules in plant stress perception (Zhou et al., 2012, 2014). Owing to its longevity, stability, and ability to cross biological membranes, $\mathrm{H}_{2} \mathrm{O}_{2}$ is the most ubiquitous intracellular messenger (Rhee et al., 2017). $\mathrm{H}_{2} \mathrm{O}_{2}$ oxidizes cysteine thiol groups of phosphatases, which are abundant in plant cells, to transmit its signal to targets (Reczek and Chandel, 2015).

Plants have developed sophisticated enzymatic and nonenzymatic mechanisms to scavenge ROS under LT conditions. Enzymes such as superoxide dismutase (SOD), ascorbate peroxidase (APX), and catalase (CAT) play major roles in scavenging $\mathrm{O}_{2}$ and $\mathrm{H}_{2} \mathrm{O}_{2}$. SOD catalyzes the dismutation of $\mathrm{O}_{2}{ }^{--}$ to $\mathrm{H}_{2} \mathrm{O}_{2}$, which is subsequently converted by APX and CAT into $\mathrm{H}_{2} \mathrm{O}$. Nonenzymatic components such as ascorbate, glutathione, carotenoids, tocopherols, and phenolic compounds (including flavonoids and anthocyanins) also serve as antioxidants and contribute to protection against ROS. The ascorbateglutathione cycle involves APX, dehydroascorbate reductase (DHAR), glutathione reductase (GR), monodehydroascorbate reductase (MDHAR), reduced ascorbic acid (AsA), reduced 
glutathione (GSH), and nicotinamide adenine dinucleotide phosphate (NADPH) in a series of cyclic reactions to detoxify $\mathrm{H}_{2} \mathrm{O}_{2}$ and regenerate AsA and GSH (Li et al., 2010).

The balance between ROS and antioxidants also functions as a signal in stress-induced anthocyanin biosynthesis. Ascorbate has been found to be an important endogenous regulator, inducing anthocyanin biosynthesis through the regulation of anthocyanin precursor biosynthesis gene expression (Page et al., 2012). Anthocyanins confer cellular protection by increasing the biosynthesis of the endogenous antioxidant GSH (Norris et al., 2016). However, how glutathione is involved in the regulation of anthocyanin remains uncertain. NADPH functions as a reducing agent and $\mathrm{H}^{+}$donor required for dihydroflavonol 4-reductase (DFR) biosynthesis (Wu et al., 2017). The production of ROS from plasma-membranelocalized NADPH oxidase plays an important role in ultraviolet ray (ultraviolet)-induced anthocyanin biosynthesis. If ultraviolet light is attenuated, the $\mathrm{O}_{2}{ }^{--}$concentration is reduced by the expression of anthocyanin biosynthesis-associated genes in Malus $\times$ domestica peel (Zhang et al., 2014). Chloroplastic $\mathrm{H}_{2} \mathrm{O}_{2}$ may also activate $F A H 1$ expression to induce anthocyanin accumulation (Maruta et al., 2014). Abscisic acid (ABA)induced $\mathrm{H}_{2} \mathrm{O}_{2}$ is required for anthocyanin accumulation in the leaves of Oryza sativa seedlings (Hung et al., 2008).

To investigate the function and mechanism of $\mathrm{H}_{2} \mathrm{O}_{2}$ in LTinduced anthocyanin biosynthesis, we employed Begonia semperflorens 'Super Olympia', a perennial evergreen plant, as the plant material for our study because its leaves turn red in LT conditions (Zhang et al., 2013). We analyzed the differences in anthocyanin biosynthesis, gene expression, $\mathrm{H}_{2} \mathrm{O}_{2}$ generation, and antioxidant levels in the presence or absence of $\mathrm{H}_{2} \mathrm{O}_{2}$ under LT conditions.

\section{Materials and Methods}

\section{Plant growth conditions and treatment}

Seeds of B. semperflorens 'Super Olympia' were sowed in $25-\mathrm{cm}$-wide pots containing a mixture of peat and vermiculite $(7: 3, \mathrm{v}: \mathrm{v})$ in a growth chamber $\left[10 \mathrm{~h}\right.$ daylength, $100 \mu \mathrm{mol} \cdot \mathrm{m}^{-2} \cdot \mathrm{s}^{-1}$ photosynthetic photon flux density $(P P F D), 25 / 15^{\circ} \mathrm{C}$ day/night temperature and $100 \%$ relative humidity]. After germination, seedlings were transplanted and supplied daily with full strength Hoagland nutrient solution in water. Seedlings with four to five leaves were employed in experiments.

EXPT. 1. Plants were treated with different concentrations of methylviologen (MV, 0.005, 0.05, 0.1, and $0.5 \mathrm{~mm}$ ) or N,N'dimethylthiourea $(1,2,5$, and $10 \mathrm{~mm})$ by foliar spraying on both the abaxial and adaxial surfaces of the leaves every day; distilled water was used as a control. Leaf samples were harvested at 0900 HR after treatment for $0,1,3,6,9$, and $15 \mathrm{~d}$.

ExPT. 2. Forty seedlings were divided into four groups. Seedlings in the first group were sprayed with distilled water and grown at $25 / 15^{\circ} \mathrm{C}$ day/night under a 10 -h photoperiod with a $P P F D$ of $300 \mu \mathrm{mol} \cdot \mathrm{m}^{-2} \cdot \mathrm{s}^{-1}$ (designated "CK"). Seedlings in the second group were sprayed with distilled water and grown at $15 / 5^{\circ} \mathrm{C}$ day/night under a 10 -h photoperiod with a $P P F D$ of $300 \mu \mathrm{mol} \cdot \mathrm{m}^{-2} \cdot \mathrm{s}^{-1}$ (designated "LT"). Seedlings in the third group were sprayed with DMTU (every other day, $5 \mathrm{~mm}$ ) and grown at $25 / 15^{\circ} \mathrm{C}$ day/night under a 10 -h photoperiod and with a PPFD of $300 \mu \mathrm{mol} \cdot \mathrm{m}^{-2} \cdot \mathrm{s}^{-1}$ (designated "DMTU"). Seedlings in the fourth group were treated with DMTU (every other day, $5 \mathrm{~mm}$ ) and grown at $15 / 5^{\circ} \mathrm{C}$ day/night under a 10 -h photoperiod and with a PPFD of $300 \mu \mathrm{mol} \cdot \mathrm{m}^{-2} \cdot \mathrm{s}^{-1}$ (designated "LT + DMTU'). Leaf samples were harvested on day 12 .

\section{Measurement of ROS}

The $\mathrm{O}_{2}{ }^{--}$production rate was measured by analyzing the formation of nitrite from hydroxylamine in the presence of $\mathrm{O}_{2}{ }^{-}$ according to the method of Elstner and Heupel (1976). Frozen leaf samples $(0.3 \mathrm{~g})$ were homogenized with $2 \mathrm{~mL}$ of potassium phosphate buffer $(65 \mathrm{~mm}, \mathrm{pH} 7.8)$ and then centrifuged at $5000 g_{\mathrm{n}}$ for $10 \mathrm{~min}$. The reaction mixture contained $0.9 \mathrm{~mL}$ of phosphate buffer, $0.1 \mathrm{~mL}$ of $10 \mathrm{~mm}$ hydroxylamine hydrochloride and $1 \mathrm{~mL}$ of supernatant. After incubation at $25{ }^{\circ} \mathrm{C}$ for $20 \mathrm{~min}, 17 \mathrm{~mm}$ sulfanilamide and $7 \mathrm{~mm} \alpha$-naphthylamine were added to the reaction mixture. An equal volume of ethylether was added, and the mixture was centrifuged at $1500 \mathrm{~g}_{\mathrm{n}}$ for 5 min. The absorbance of the aqueous solution was read at $530 \mathrm{~nm}$.

Leaf $\mathrm{H}_{2} \mathrm{O}_{2}$ content was measured by monitoring absorbance of the titanium-peroxide complex at $415 \mathrm{~nm}$ according to the method of Brennan and Frenkel (1977). Frozen leaf samples $(0.3 \mathrm{~g})$ were homogenized with $2 \mathrm{~mL}$ of cold acetone. After centrifugation at $12,000 \mathrm{~g}_{\mathrm{n}}$ for $5 \mathrm{~min}$, the supernatant was collected to determine $\mathrm{H}_{2} \mathrm{O}_{2}$ content. The assay mixture contained $0.5 \mathrm{~mL}$ of the extract, $50 \mu \mathrm{L}$ titanium reagent $(20 \%$ titanium tetrachloride in concentrated $\mathrm{HCl}, \mathrm{v} / \mathrm{v}$ ), and $0.1 \mathrm{~mL}$ of $\mathrm{NH}_{3} \cdot \mathrm{H}_{2} \mathrm{O}(25 \%)$. After centrifugation at $10,000 \mathrm{~g}_{\mathrm{n}}$ for $5 \mathrm{~min}$, the pellets were washed with $1 \mathrm{~mL}$ of acetone for five times, and then dissolved in $3 \mathrm{~mL}$ of $2 \mathrm{M} \mathrm{H}_{2} \mathrm{SO}_{4}$. Absorbance of the solution was read at $415 \mathrm{~nm}$.

\section{Determination of activities of enzymes}

Frozen leaf samples $(0.3 \mathrm{~g})$ were homogenized in $3 \mathrm{~mL}$ of potassium phosphate buffer $(50 \mathrm{~mm}, \mathrm{pH} 7.8)$ containing $0.2 \mathrm{~mm}$ EDTA, $2 \mathrm{~mm}$ ascorbate, and 2\% (w/v) PVP. The homogenate was centrifuged for $20 \mathrm{~min}$ at $12,000 \mathrm{~g}_{\mathrm{n}}$, and the supernatant was used for SOD, CAT enzyme analysis. All operations were performed at 0 to $4{ }^{\circ} \mathrm{C}$. Antioxidant enzyme activities were determined as described by Zhou et al. (2004).

Glutathione reductase [GR (EC 1.6.4.2)] activity was analyzed on the basis of the rate of decrease in absorbance at $340 \mathrm{~nm}$ caused by NADPH oxidation Foyer and Halliwell (1976). MDHAR (EC 1.6.5.4) activity was measured by monitoring the decrease in absorbance at $340 \mathrm{~nm}$ because of the NADH oxidation (Arrigoni et al., 1981). DHAR (EC1.8.5.1) activity was measured by following the formation of AsA from dehydroascorbate (DHA) at $265 \mathrm{~nm}$ according to Dalton et al. (1986). APX (EC 1.11.1.11) activity was determined according to Nakano and Asada (1981) by monitoring the rate of ascorbate oxidation at $290 \mathrm{~nm}$.

\section{Determination of nonenzymatic antioxidants}

Frozen leaf sample $(0.3 \mathrm{~g})$ was homogenized in $2 \mathrm{~mL}$ of $2 \%$ metaphosphoric acid containing $2 \mathrm{~mm}$ EDTA. After centrifugation for $10 \mathrm{~min}$ at $14,000 \mathrm{~g}_{\mathrm{n}}$, the supernatant was used for measuring contents of AsA, DHA, GSH, and oxidized glutathione (GSSG). Protein content was determined according to the method of Bradford (1976) using bovine serum albumin as the standard.

AsA and DHA were measured following Law et al. (1983). To determine contents of AsA and DHA, half of the sample extract was incubated for $50 \mathrm{~min}$ with $200 \mathrm{~mm}$ phosphate buffer solution (pH 7.4) and 1.5 mM DTT. After incubation, $200 \mu \mathrm{L}$ of 
$0.5 \%(\mathrm{w} / \mathrm{v})$ N-ethylmaleimide (NEM) was added to remove excess DTT. The other half of sample extract was used to determine AsA content in a similar manner except that $400 \mu \mathrm{L}$ deionized $\mathrm{H}_{2} \mathrm{O}$ was substituted for DTT and NEM. Color was developed in both series of reaction mixtures (total and reduced ascorbate) with the addition of $400 \mu \mathrm{L} 10 \%$ (w/v) trichloroacetic acid, $400 \mu \mathrm{L} \mathrm{44 \%} \mathrm{H}_{3} \mathrm{PO}_{4}, 400 \mu \mathrm{L} \mathrm{4 \%} \alpha$-dipyridyl in $70 \%$ ethanol and $200 \mu \mathrm{L} \mathrm{3 \%}(\mathrm{w} / \mathrm{v}) \mathrm{FeCl}_{3}$. After incubating at $37^{\circ} \mathrm{C}$ for $60 \mathrm{~min}$ in a water bath, the reaction mixtures were measured spectrophotometrically at $525 \mathrm{~nm}$. DHA concentration was obtained by subtracting AsA concentration from the total concentration.

GSH and GSSG were measured following Rao and Ormrod (1995) with minor modifications. To determine contents of GSH and GSSG, $0.1 \mathrm{~mL}$ of sample extract was first neutralized with $0.5 \mathrm{M}$ phosphate buffer $(\mathrm{pH} 7.5)$. The reaction mixture contained $100 \mathrm{~mm}$ phosphate buffer $(\mathrm{pH} 7.5), 5 \mathrm{~mm}$ EDTA, $0.6 \mathrm{~mm} 5,5^{\prime}$-dithio-bis (2-nitrobenzoicacid) and 0.2 mm NADPH. After adding $3 \mathrm{U}$ of yeast GR, the changes of absorbance in $412 \mathrm{~nm}$ for $1 \mathrm{~min}$ were recorded. For determine GSSG content, $0.5 \mathrm{~mL}$ of neutralized sample extract was mixed with $0.01 \mathrm{~mL}$ of 2-vinylpyridine. GSH concentration was obtained by subtracting GSSG concentration from the total concentration.

$\mathrm{NADP}^{+}$and NADPH were measured following Gibon and Larher (1997) with minor modifications. Leaf sample (0.1 g) was homogenized with $0.9 \mathrm{~mL}$ of $0.1 \mathrm{~N} \mathrm{NaOH}$ for NADPH analysis, $0.9 \mathrm{~mL}$ of $0.1 \mathrm{~N} \mathrm{HCl}$ for $\mathrm{NADP}^{+}$analysis. The homogenates were heated in a boiling water bath for $5 \mathrm{~min}$. After cooled immediately, the homogenates were centrifuged at $10,000 \mathrm{~g}_{\mathrm{n}}$ for $10 \mathrm{~min}$. The reaction mixture contained $400 \mathrm{~mm}$ $\mathrm{NaCl}, 100 \mathrm{~mm}$ Tris-HCl pH 8.0, 4 mм EDTA, 0.42 mм 3-(4,5dimethylthiazolyl-2)-2,5-diphenyltetrazolium bromide (MTT), $1.66 \mathrm{~mm}$ phenzine ethosulfate (PES), $14 \mathrm{U}$ of glucose 6phosphate dehydrogenase $(\mathrm{G} 6 \mathrm{PDH})$ at $37^{\circ} \mathrm{C}$ for $40 \mathrm{~min}$. The reaction was stopped by addition of $500 \mu \mathrm{L}$ of $5 \mathrm{M} \mathrm{NaCl}$, then centrifuged at $20,000 g_{\mathrm{n}}$ at $4{ }^{\circ} \mathrm{C}$ for $5 \mathrm{~min}$. The pellets were lysed in $1 \mathrm{~mL}$ of $98 \%$ ethanol and the absorbance at $570 \mathrm{~nm}$ was measured on a spectrophotometer.

\section{Anthocyanin quantification}

Anthocyanin contents were determined according to the methods described by Mita et al. (1997), with minor modifications. Leaf samples $(0.3 \mathrm{~g})$ were ground with $3 \mathrm{~mL}$ of $1 \%(\mathrm{v} / \mathrm{v})$ $\mathrm{HCl}: \mathrm{MeOH}$ and then maintained under dark conditions at $4{ }^{\circ} \mathrm{C}$ for $1 \mathrm{~d}$. After centrifugation at $3500 \mathrm{~g}_{\mathrm{n}}$ for $15 \mathrm{~min}$, the supernatant was measured spectrophotometrically at 530 and $657 \mathrm{~nm}$. One unit of anthocyanin equals one absorbance unit (A530-0.25 $\times$ A657) per milliliter of extraction solution.

\section{Gene expression analysis}

Gene expression of phenylalanine ammonialyase $[B s P A L$ (Genbank accession no. KJ930039)], chalcone synthase [BsCHS (Genbank accession no. KJ930037)], flavanone 3hydroxylas [ $B s F 3 H$ (Genbank accession no. KJ930038)], and anthocyanidin synthase [BSANS (Genbank accession no. KJ930039)] was examined by real-time quantitative RT-qPCR analysis. Total RNA was extracted from mixed leaf samples from three seedlings at each time point from each treatment using the CTAB method according to Liao et al. (2004) Firststrand cDNA was synthetized using the Prime ScriptTM RT Reagent Kit with gDNA Eraser (TaKaRa Bio, Dalian, China). The gene-specific primers used for real-time RT-qPCR analysis were designed using Genescript software (GenScript Biotech Corp., Nanjing, China) (Supplemental Table 1). The $18 S$ rRNA gene (Genbank accession no. KJ959633) from B. semperflorens was used as the internal reference gene to normalize any differences in the amount of each cDNA template. The RTqPCR cycling conditions were as follows: $95{ }^{\circ} \mathrm{C}$ for $10 \mathrm{~s}$, followed by 40 cycles of $95{ }^{\circ} \mathrm{C}$ for $10 \mathrm{~s}$ and $60{ }^{\circ} \mathrm{C}$ for $45 \mathrm{~s}$. We employed the $2^{-\triangle \triangle \mathrm{CT}}$ method (Livak and Schmittgen, 2001) to analyze relative gene expression based on three biological replicates. The data and figures were generated using SPSS (version 16.0; IBM Corp., Armonk, NY) and Origin (version 8; OriginLab, Northampton, MA) software.

\section{Measurement of Chlorophyll fluorescence}

Chlorophyll fluorescence was measured with a pulse modulated fluorometer (FMS22; Hansatech Instruments, Norfolk, UK). Seedlings were dark adapted for at least $30 \mathrm{~min}$ before measurement of the photochemical quenching coefficient (qP). Minimal fluorescence $\left(\mathrm{F}_{\mathrm{o}}\right)$ was measured under a weak modulating light, and maximal fluorescence $\left(\mathrm{F}_{\mathrm{m}}\right)$ was induced by a saturating pulse of light $\left(4000 \mu \mathrm{mol} \cdot \mathrm{m}^{-2} \cdot \mathrm{s}^{-1}\right)$ applied over $0.8 \mathrm{~s} . \mathrm{F}_{\mathrm{v}}$ is the difference between $\mathrm{F}_{\mathrm{o}}$ and $\mathrm{F}_{\mathrm{m}}$. An actinic light source was then applied to achieve a steady state of photosynthesis and to obtain steady state fluorescence yield $\left(\mathrm{F}_{\mathrm{s}}\right)$, after which a second saturation pulse was applied for $0.7 \mathrm{~s}$ to obtain light adapted maximum fluorescence $\left(\mathrm{F}_{\mathrm{m}}{ }^{\prime}\right)$. $\mathrm{qP}$ was calculated as $\left(\mathrm{F}_{\mathrm{m}}{ }^{\prime}-\mathrm{F}_{\mathrm{s}}\right) /\left(\mathrm{F}_{\mathrm{m}}{ }^{\prime}-\mathrm{F}_{\mathrm{o}}{ }^{\prime}\right)$ according to Zhou et al. (2004). All the measurements were measured at $1000 \mathrm{HR}$.

\section{Statistical analysis}

Data from four to six replicates per treatment were analyzed. Means were analyzed using a one-way analysis of variance using Data Processing System software [DPS 3.01 (Tang and Feng, 2002)]. Multiple comparisons between means were conducted using Tukey's test at $P<0.05$.

\section{Results}

\section{Effect of MV and DMTU on ROS and anthocyanin accumulation}

Treatment of DMTU had negative effect on $\mathrm{H}_{2} \mathrm{O}_{2}$ content and $\mathrm{O}_{2}{ }^{--}$production rate in B. semperflorens (Fig. 1A and $\mathrm{C}$ ). Over the first $6 \mathrm{~d}$, DMTU treatment decreased the $\mathrm{H}_{2} \mathrm{O}_{2}$ content and $\mathrm{O}_{2}{ }^{--}$production rate in a dose-dependent manner. From days 9 to 15 , the $\mathrm{H}_{2} \mathrm{O}_{2}$ content and $\mathrm{O}_{2}{ }^{-}$production rate in DMTU-treated seedlings (except for the seedlings treated with $10 \mathrm{~mm}$ DMTU) returned to the levels observed in seedlings in the CK group. With the exception of the lowest concentration $(0.005 \mathrm{mM})$ of $\mathrm{MV}, \mathrm{MV}$ treatment increased the $\mathrm{H}_{2} \mathrm{O}_{2}$ content and $\mathrm{O}_{2}{ }^{--}$production rate in B. semperflorens (Fig. $1 \mathrm{~B}$ and $\mathrm{D}$ ). ROS accumulation increased over time in seedlings treated with $0.5 \mathrm{~mm} \mathrm{MV}$, whereas in plants treated with 0.05 and $0.1 \mathrm{~mm} \mathrm{MV}$, ROS accumulation significantly increased starting at day 1 and peaked at day 6 .

DMTU had no significant effect on anthocyanin content at any treatment concentration (Fig. 1E). Treatment with 0.005 and $0.5 \mathrm{~mm} \mathrm{MV}$ had no significant effect on anthocyanin content, whereas treatment with 0.05 and $0.1 \mathrm{~mm} \mathrm{MV}$ significantly increased anthocyanin content by day 3, and the level then plateaued at day 9 in B. semperflorens (Fig. 1F).

These results suggested that anthocyanin accumulation may be related to ROS accumulation; thus, ROS accumulation may be an inducer of anthocyanin biosynthesis in B. semperflorens. 


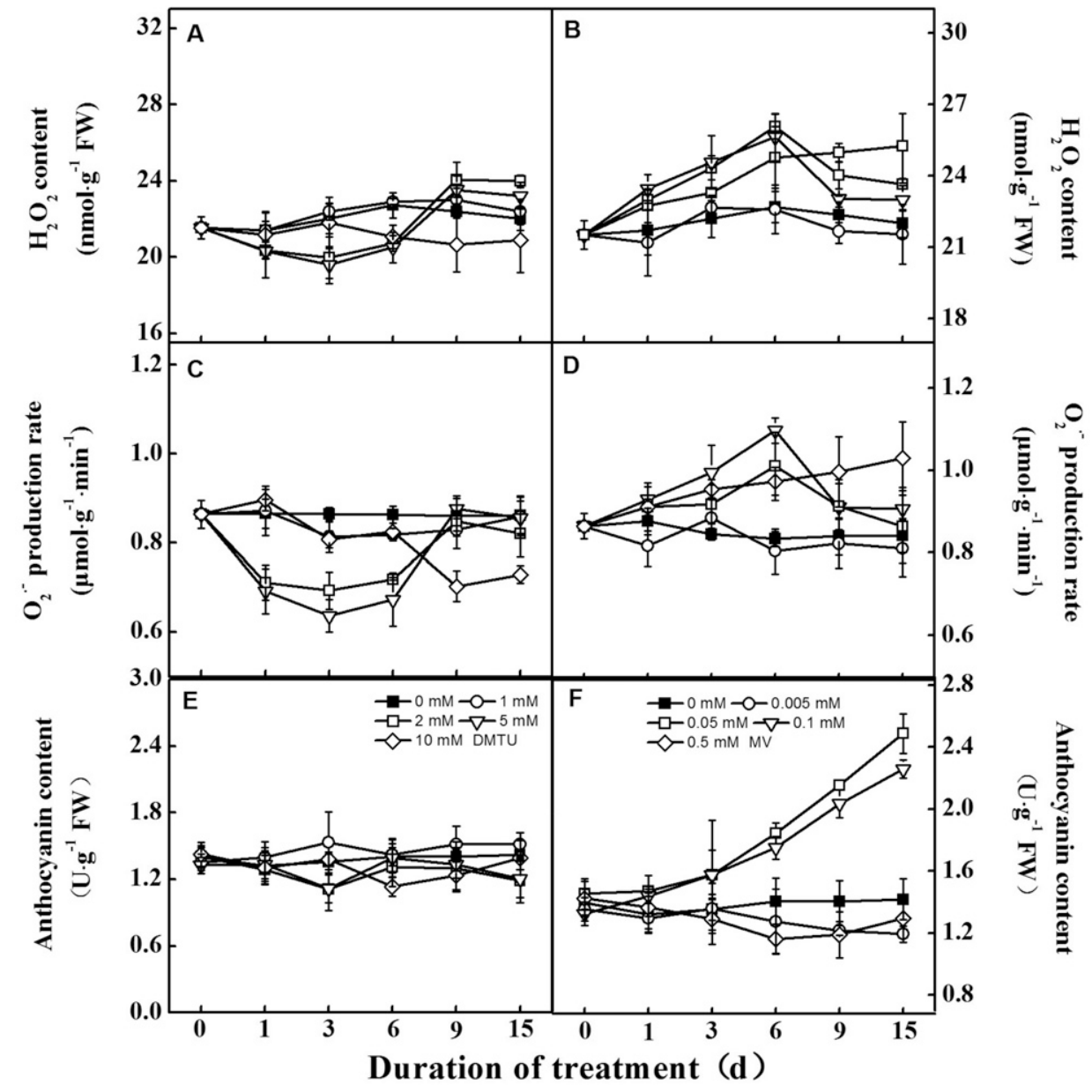

Fig. 1. The dose-dependent response of hydrogen peroxide $\left(\mathrm{H}_{2} \mathrm{O}_{2}\right)$ contents $(\mathbf{A}$ and $\mathbf{B})$, superoxide anions $\left(\mathrm{O}_{2}{ }^{--}\right)$ production rate $(\mathbf{C}$ and $\mathbf{D})$, and anthocyanin contents $(\mathbf{E}$ and $\mathbf{F})$ to exogenous N,N'-dimethylthiourea [DMTU (1, $2,5$, and $10 \mathrm{~mm})]$ and methylviologen $[\mathrm{MV}(0.005,0.05,0.1$, and $0.5 \mathrm{~mm})]$ in leaves of Begonia semperflorens. Leaf samples were harvested at $0900 \mathrm{HR}$ after different treatments for $0,1,3,6,9$, and $15 \mathrm{~d}$. Values and error bars indicate means \pm SD $(\mathrm{n}=3-6)$. Means denoted by the same letter do not significantly differ at $P<0.05$ in a single group according to Tukey's test.

Effects of LT and DMTU on anthocyanin and ROS accumulation and the expression of genes involved in anthocyanin biosynthesis

To further explore the relationship between anthocyanin content and ROS accumulation, we verified the effect of DMTU ( $5 \mathrm{~mm}$ ) on LT-induced anthocyanin biosynthesis, a phenomenon reported in our previous studies (Zhang et al., 2013, 2016).

As shown in Fig. 2E-H, LT significantly increased ROS and anthocyanin accumulation, while DMTU had no significant effect on either. Compared with the LT condition, the combination of LT and DMTU treatment (LT + DMTU) significantly decreased the $\mathrm{H}_{2} \mathrm{O}_{2}$ content and $\mathrm{O}_{2}{ }^{*-}$ production rate. Although seedlings in the LT + DMTU group had a higher $\mathrm{O}_{2}{ }^{-}$production rate than seedlings in the $\mathrm{CK}$ group, no significant difference in $\mathrm{H}_{2} \mathrm{O}_{2}$ content was observed between seedlings in the $\mathrm{CK}$ and LT + DMTU groups.

Changes in anthocyanin contents were in line with ROS accumulation: LT increased the anthocyanin content in B. semperflorens, while treatment with $5 \mathrm{~mm}$ DMTU prevented this increase (Fig. 2E-H). These results suggested that ROS accumulation corresponded to anthocyanin content in B. semperflorens.

To explore the function of ROS in promoting anthocyanin accumulation, we analyzed the expression of genes involved in anthocyanin biosynthesis. As shown in Fig. 2A-D, LT significantly upregulated the expression of $B S P A L$, $B s C H S, B s F 3 H$, and $B s A N S$. DMTU down-regulated $B s P A L$ and $B s C H S$ expression, but had no effect on the expression of $B S F 3 H$ and $B S A N S$. Compared with seedlings in the LT group, the expression levels of all four genes were down-regulated in seedlings exposed to LT and DMTU treatment. We therefore concluded that the combination of LT and DMTU regulated anthocyanin content at the transcriptional level by modulating the expression of late biosynthesis-related genes.

\section{Effects of LT and DMTU on chlorophyll fluorescence, enzyme activities, and AsA-GSH-controlled redox homeostasis}

In $B$. semperflorens, the activities of antioxidant enzymes, including SOD, CAT, APX, MDHAR, DHAR, and GR, were unaffected by DMTU treatment, while they were increased under LT conditions (Fig. 3). The combination of LT and DMTU treatment decreased the activities of these four enzymes in B. semperflorens compared with LT alone. The activities of SOD and MDHAR were higher in seedlings in the LT + DMTU group than in seedlings in the $\mathrm{CK}$ group, while no significant differences in the activities of four other enzymes (CAT, DHAR, APX, and GR) were observed between the two groups (Fig. 3).

As shown in Table 1, LT increased AsA, GSH, and NADPH contents and decreased DHA, GSSG, and NADP ${ }^{+}$contents. Compared with LT alone, the combination of DMTU treatment and LT decreased the contents of AsA, GSH, and NADPH in $B$. semperflorens to the same levels as those observed in seedlings in the CK group.

As shown in Table 2, DMTU treatment had no effects on $\mathrm{F}_{\mathrm{m}}, \mathrm{F}_{\mathrm{o}}, \mathrm{qP}$, and $\mathrm{F}_{\mathrm{v}} / \mathrm{F}_{\mathrm{m}}$. LT decreased the level of $\mathrm{F}_{\mathrm{m}}$ and $\mathrm{qP}$, and had no effect on the level of $F_{o}$. As a result, the level of $F_{v} / F_{m}$ significantly decreased in seedlings in LT group. The combination of DMTU treatment and LT showed the same effects on $\mathrm{F}_{\mathrm{m}}, \mathrm{qP}$, and $\mathrm{F}_{\mathrm{o}}$.

\section{Discussion}

ROS may induce anthocyanin accumulation in $B$. semperflorens

ROS, especially $\mathrm{H}_{2} \mathrm{O}_{2}$ and $\mathrm{O}_{2}{ }^{-}$, function as signaling molecules in many physiological processes. DMTU treatment decreased $\mathrm{H}_{2} \mathrm{O}_{2}$ and $\mathrm{O}_{2}{ }^{--}$levels in $B$. semperflorens, an effect that diminished gradually over $6 \mathrm{~d}$ (Fig. 1A and C). Although different concentrations showed different trends, the application of $\mathrm{MV}$ promoted $\mathrm{H}_{2} \mathrm{O}_{2}$ and $\mathrm{O}_{2}{ }^{--}$accumulation in 


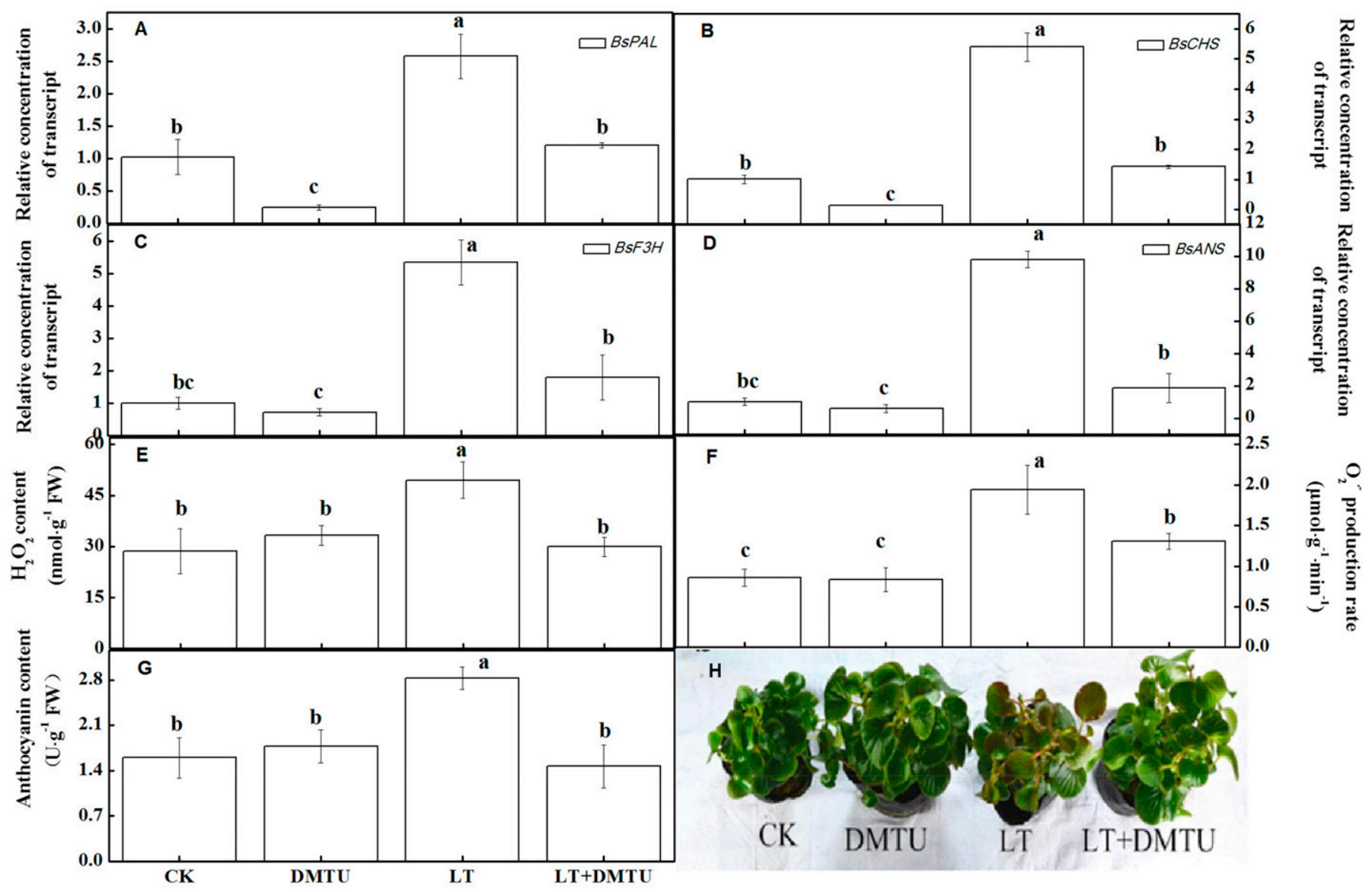

Fig. 2. Effects of low temperature [LT $\left(15 / 5^{\circ} \mathrm{C}\right.$ day/night $\left.)\right]$ and $\mathrm{N}, \mathrm{N}^{\prime}$-dimethylthiourea [DMTU $\left.(5 \mathrm{mM})\right]$ on relative transcript levels for four key genes in anthocyanin biosynthesis $[B s P A L(\mathbf{A}), B s C H S(\mathbf{B}), B s F 3 H(\mathbf{C})$, and $B s A N S(\mathbf{D})]$, hydrogen peroxide $\left(\mathrm{H}_{2} \mathrm{O}_{2}\right)$ contents $(\mathbf{E})$, superoxide anions $\left(\mathrm{O}_{2}{ }^{-}\right)$production rate $(\mathbf{F})$, and anthocyanin contents $(\mathbf{G})$ in leaves of Begonia semperflorens. Leaf samples were harvested on day 12. Seedlings were sprayed with distilled water and grown at $25 / 15^{\circ} \mathrm{C}$ day/night (CK); seedlings were sprayed with distilled water and grown at $15 / 5^{\circ} \mathrm{C}$ day/night (LT); seedlings were sprayed with DMTU (every other day, $5 \mathrm{mM}$ ) and grown at $25 / 15^{\circ} \mathrm{C}$ day/night (DMTU); seedlings were sprayed with DMTU (every other day, $5 \mathrm{~mm}$ ) and grown at $15 / 5{ }^{\circ} \mathrm{C}$ day/night $(\mathrm{LT}+$ DMTU). Values and error bars indicate means $\pm \mathrm{SD}(\mathrm{n}=3-6)$. Means denoted by the same letter do not significantly differ at $P<0.05$ in a single group according to Tukey's test.

B. semperflorens (Fig. 1B and D). These results suggested that DMTU and MV treatments were effective in our experiments.

While DMTU had no effect on anthocyanin content (Fig. $1 \mathrm{E})$, concentrations of MV ( 0.05 and $0.1 \mathrm{~mm})$ that significantly promoted $\mathrm{H}_{2} \mathrm{O}_{2}$ and $\mathrm{O}_{2}{ }^{-}$accumulation (Fig. 1B and D) also significantly induced anthocyanin accumulation (Fig. 1F).

By up-regulating late biosynthetic and corresponding regulatory genes, ROS may induce anthocyanin accumulation in $A$. thaliana (Xu et al., 2017). Chloroplastic $\mathrm{H}_{2} \mathrm{O}_{2}$ may activate FAH1 expression to induce anthocyanin accumulation (Maruta et al., 2014). If ultraviolet light is attenuated, the $\mathrm{O}_{2}{ }^{-}$concentration and the expression of anthocyanin biosynthesisassociated genes is reduced in apple peel (Zhang et al., 2014). ABA-induced $\mathrm{H}_{2} \mathrm{O}_{2}$ is required for anthocyanin accumulation in the leaves of rice seedlings (Hung et al., 2008). We therefore hypothesized that the application of MV induced anthocyanin accumulation by increasing $\mathrm{H}_{2} \mathrm{O}_{2}$ and $\mathrm{O}_{2}{ }^{-*}$ levels.

\section{ROS was involved in LT-induced anthocyanin biosynthesis in \\ B. semperflorens}

Our previous studies showed that the leaves of B. semperflorens turned red and produced anthocyanin under LT conditions (Zhang et al., 2013, 2016). To explore the mechanism of
ROS-mediated induction of anthocyanin biosynthesis, we analyzed the changes in anthocyanin content and ROS production in B. semperflorens under LT conditions.

LT conditions of $15 / 5{ }^{\circ} \mathrm{C}$ led to a decrease in $\mathrm{F}_{\mathrm{v}} / \mathrm{F}_{\mathrm{m}}$ (Table 2), implying photoinhibition occurred in LT-exposed seedlings. A decrease in $F_{v} / F_{m}$ was the result of a decline in $F_{m}$ with no increase in $\mathrm{F}_{\mathrm{o}}$; photoinhibition (a decrease in $\mathrm{F}_{\mathrm{v}} / \mathrm{F}_{\mathrm{m}}$ level) was ascribed to the conformational changes in photosystem II (PSII) related to thermal energy dissipation (Pagliano et al., 2006). Additional application of DMTU alleviated the photoinhibition caused by LT treatment through scavenging ROS (Fig. 2).

As shown in Fig. 3 and Table 1, the levels of both enzymatic antioxidants (SOD, CAT, and APX) and nonenzymatic antioxidants (AsA and GSH) were significantly increased in response to the oxidative stress caused by LT. LT-exposed seedlings still exhibited a lower $\mathrm{O}_{2}{ }^{--}$production rate and $\mathrm{H}_{2} \mathrm{O}_{2}$ content than seedlings in the CK group (Fig. 1).

By increasing the contents of AsA, GSH, and NADPH while decreasing the contents of DHA, GSSG, and $\mathrm{NADP}^{+}, \mathrm{LT}$ increased the ratios of AsA/DHA, GSH/GSSG, and NADPH/ $\mathrm{NADP}^{+}$in LT-exposed seedlings (Table 1). Higher ratios of AsA/DHA, GSH/GSSG, and NADPH/NADP ${ }^{+}$may trigger the reduction of cysteine residues, which then act as retrograde 


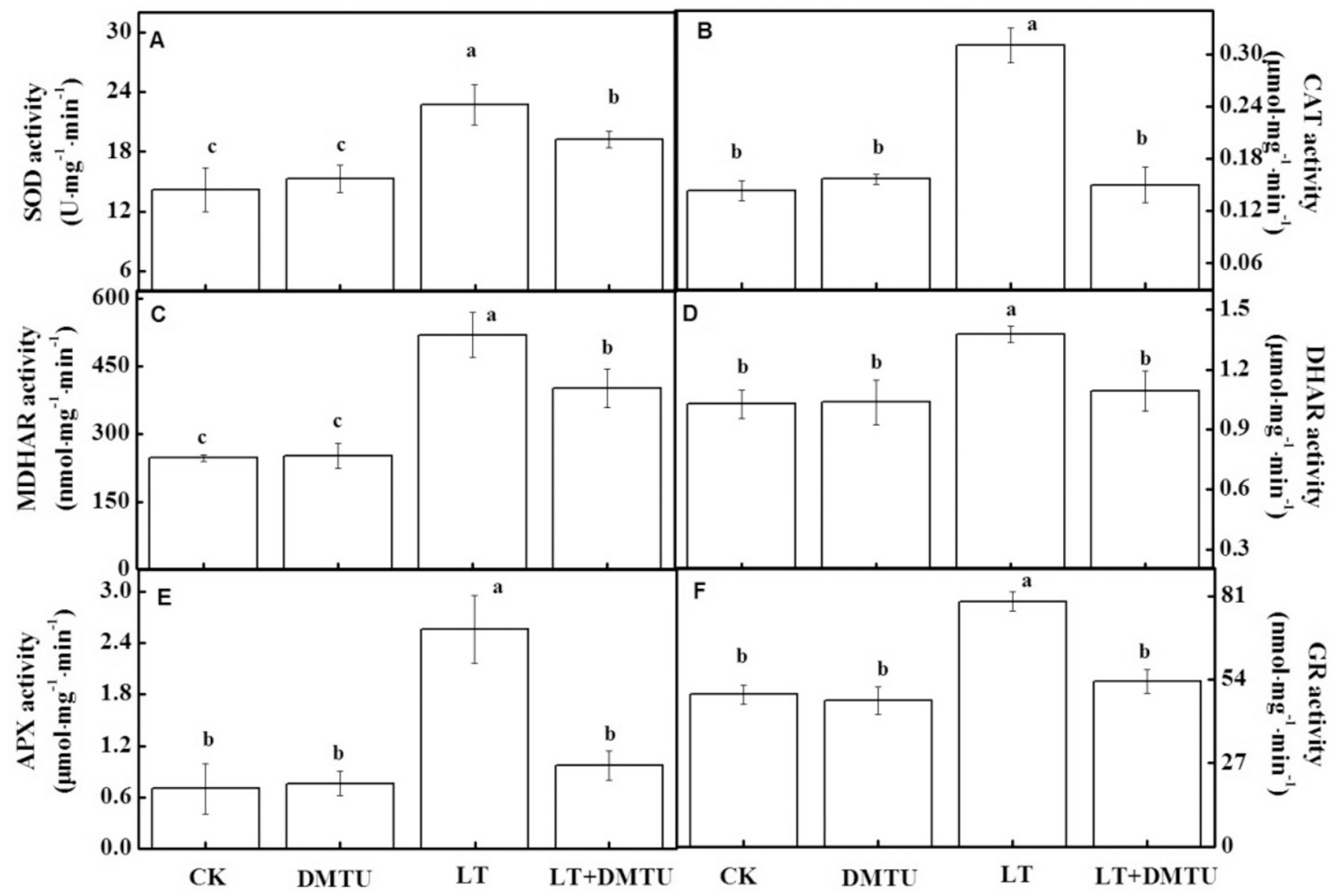

Fig. 3. Effects of low temperature [LT $\left(15 / 5^{\circ} \mathrm{C}\right.$ day/night)] and $\mathrm{N}, \mathrm{N}^{\prime}$-dimethylthiourea [DMTU (5 mM)] on activities of superoxide dismutase [SOD (A)], catalase [CAT (B)], monodehydroascorbate reductase [MDHAR (C)], dehydroascorbate reductase [DHAR (D)], ascorbate peroxidase [APX (E)], and glutathione reductase [GR (F)] in leaves of Begonia semperflorens. Leaf samples were harvested on day 12. Seedlings were sprayed with distilled water and grown at $25 / 15^{\circ} \mathrm{C}$ day/night (CK); seedlings were sprayed with distilled water and grown at $15 / 5{ }^{\circ} \mathrm{C}$ day/night (LT); seedlings were sprayed with DMTU (every other day, $5 \mathrm{~mm}$ ) and grown at $25 / 15^{\circ} \mathrm{C}$ day/night (DMTU); seedlings were sprayed with DMTU (every other day, $5 \mathrm{~mm}$ ) and grown at $15 / 5{ }^{\circ} \mathrm{C}$ day/ night $(\mathrm{LT}+\mathrm{DMTU})$. Values and error bars indicate means $\pm \mathrm{SD}(\mathrm{n}=3-6)$. Means denoted by the same letter do not significantly differ at $P<0.05$ in a single group according to Tukey's test.

Table 1. Effects of low temperature $\left[\mathrm{LT}\left(15 / 5^{\circ} \mathrm{C}\right.\right.$ day/night $\left.)\right]$ and $\mathrm{N}, \mathrm{N}^{\prime}$-dimethylthiourea [DMTU $(5 \mathrm{mM})]$ on the contents of components involved in the ascorbate-glutathione cycle [ascorbate peroxidase (APX), reduced ascorbic acid (AsA), dehydroascorbate (DHA), reduced glutathione (GSH), oxidized glutathione (GSSG), nicotinamide adenine dinucleotide phosphate (NAPPH), and nicotinamide adenine dinucleotide phosphate $\left.\left(\mathrm{NADP}^{+}\right)\right]$in leaves of Begonia semperflorens. ${ }^{\mathrm{z}}$

\begin{tabular}{lcccr}
\hline Content or ratio & CK & DMTU & LT & LT + DMTU \\
\hline AsA $\left(\mu \mathrm{mol} \cdot \mathrm{g}^{-1} \mathrm{FW}\right)$ & $2.33 \pm 0.24 \mathrm{~b}$ & $2.11 \pm 0.22 \mathrm{~b}$ & $3.59 \pm 0.25 \mathrm{a}$ & $2.40 \pm 0.03 \mathrm{~b}$ \\
DHA $\left(\mu \mathrm{mol} \cdot \mathrm{g}^{-1} \mathrm{FW}\right)$ & $0.68 \pm 0.04 \mathrm{a}$ & $0.62 \pm 0.05 \mathrm{a}$ & $0.36 \pm 0.03 \mathrm{~b}$ & $0.59 \pm 0.04 \mathrm{a}$ \\
AsA $/ \mathrm{DHA}$ & $3.45 \pm 0.24 \mathrm{~b}$ & $3.42 \pm 0.16 \mathrm{~b}$ & $9.90 \pm 1.07 \mathrm{a}$ & $4.07 \pm 0.32 \mathrm{~b}$ \\
$\mathrm{GSH}\left(\mathrm{nmol} \cdot \mathrm{g}^{-1} \mathrm{FW}\right)$ & $208.75 \pm 20.02 \mathrm{~b}$ & $226.59 \pm 17.89 \mathrm{~b}$ & $302.66 \pm 48.14 \mathrm{a}$ & $239.46 \pm 28.42 \mathrm{~b}$ \\
$\mathrm{GSSG}\left(\mathrm{nmol} \cdot \mathrm{g}^{-1} \mathrm{FW}\right)$ & $16.64 \pm 0.18 \mathrm{~b}$ & $18.89 \pm 1.08 \mathrm{~b}$ & $9.89 \pm 1.08 \mathrm{c}$ & $29.15 \pm 4.09 \mathrm{a}$ \\
$\mathrm{GSH} / \mathrm{GSSG}$ & $12.54 \pm 1.16 \mathrm{~b}$ & $12.04 \pm 1.47 \mathrm{~b}$ & $31.15 \pm 7.81 \mathrm{a}$ & $8.38 \pm 1.94 \mathrm{~b}$ \\
$\mathrm{NADPH}\left(\mathrm{nmol} \cdot \mathrm{g}^{-1} \mathrm{FW}\right)$ & $5.49 \pm 0.57 \mathrm{~b}$ & $5.35 \pm 0.63 \mathrm{~b}$ & $11.35 \pm 0.59 \mathrm{a}$ & $5.99 \pm 0.33 \mathrm{~b}$ \\
$\mathrm{NADP}^{+}\left(\mathrm{nmol} \cdot \mathrm{g}^{-1} \mathrm{FW}\right)$ & $12.20 \pm 0.48 \mathrm{a}$ & $9.09 \pm 0.53 \mathrm{~b}$ & $7.67 \pm 0.41 \mathrm{c}$ & $7.98 \pm 1.03 \mathrm{bc}$ \\
$\mathrm{NADPH}^{\mathrm{N}} \mathrm{NADP}^{+}$ & $0.45 \pm 0.06 \mathrm{c}$ & $0.59 \pm 0.04 \mathrm{bc}$ & $1.49 \pm 0.15 \mathrm{a}$ & $0.76 \pm 0.13 \mathrm{~b}$
\end{tabular}

${ }^{\mathrm{z}}$ Leaf samples were harvested on day 12. Seedlings were sprayed with distilled water and grown at $25 /$ $15^{\circ} \mathrm{C}$ day/night (CK); seedlings were sprayed with distilled water and grown under low temperature of $15 / 5^{\circ} \mathrm{C}$ day/night (LT); seedlings were sprayed with DMTU [every other day (5 mM)] and grown under low temperature of $25 / 15^{\circ} \mathrm{C}$ day/night (DMTU); seedlings were sprayed with DMTU [every other day (5 mM)] and grown at $15 / 5^{\circ} \mathrm{C}$ day/night (LT + DMTU). Values and error bars indicate means \pm SD $(\mathrm{n}=3-6)$. Means denoted by the same letter do not significantly differ at $P<0.05$ in a single group according to Tukey's test. signals from chloroplasts to nucleus (Noctor and Foyer, 2016). Ascorbate has been found to be an important endogenous regulator, inducing anthocyanin biosynthesis via the regulation of anthocyanin precursor biosynthesis gene expression (Page et al., 2012). Anthocyanins protect cells by increasing the biosynthesis of the endogenous antioxidant GSH (Norris et al., 2016). However, how glutathione is involved in the regulation of anthocyanin metabolism remains uncertain. NADPH functions as a reducing agent and $\mathrm{H}^{+}$ donor required for DFR biosynthesis (Wu et al., 2017).

Based on the results above, we therefore suggested that the expression levels of genes involved in anthocyanin biosynthesis (BSPAL, $B s C H S, B s F 3 H$, and $B s A N S$ ) were 
Table 2. Effects of low temperature [LT $\left(15 / 5{ }^{\circ} \mathrm{C}\right.$ day/night $\left.)\right]$ and N,N'-dimethylthiourea [DMTU $(5 \mathrm{~mm})]$ on chlorophyll fluorescence in leaves of Begonia semperflorens. ${ }^{\mathrm{z}}$

\begin{tabular}{lrccc}
\hline Treatment & $\mathrm{F}_{\mathrm{m}}$ & $\mathrm{F}_{\mathrm{o}}$ & $\mathrm{qP}$ & $\mathrm{F}_{\mathrm{v}} / \mathrm{F}_{\mathrm{m}}$ \\
\hline CK & $2101.50 \pm 352.07 \mathrm{a}$ & $372.50 \pm 19.97 \mathrm{a}$ & $0.81 \pm 0.02 \mathrm{a}$ & $0.82 \pm 0.03 \mathrm{a}$ \\
DMTU & $2088.75 \pm 371.47 \mathrm{a}$ & $356.00 \pm 23.04 \mathrm{a}$ & $0.82 \pm 0.04 \mathrm{a}$ & $0.83 \pm 0.03 \mathrm{a}$ \\
LT & $996.50 \pm 187.46 \mathrm{c}$ & $367.75 \pm 13.50 \mathrm{a}$ & $0.47 \pm 0.03 \mathrm{c}$ & $0.62 \pm 0.08 \mathrm{~b}$ \\
LT + DMTU & $1439.00 \pm 280.79 \mathrm{~b}$ & $354.50 \pm 13.03 \mathrm{a}$ & $0.68 \pm 0.086 \mathrm{~b}$ & $0.75 \pm 0.05 \mathrm{ab}$ \\
\hline
\end{tabular}

${ }^{\mathrm{z}}$ Leaf samples were harvested on day 12. Seedlings were sprayed with distilled water and grown at $25 / 15^{\circ} \mathrm{C}$ day/night $(\mathrm{CK})$; seedlings were sprayed with distilled water and grown at $15 / 5^{\circ} \mathrm{C}$ day/night (LT); seedlings were sprayed with DMTU [every other day (5 mM)] and grown at $25 / 15^{\circ} \mathrm{C}$ day/night (DMTU); seedlings were sprayed with DMTU [every other day $(5 \mathrm{~mm})$ ] and grown at $15 / 5{ }^{\circ} \mathrm{C}$ day/ night $(\mathrm{LT}+\mathrm{DMTU})$. Values and error bars indicate mean $\pm \mathrm{SD}(\mathrm{n}=3-6)$. Means denoted by the same letter do not significantly differ at $P<0.05$ in a single group according to Tukey's test.

$\mathrm{F}_{\mathrm{m}}=$ maximal fluorescence; $\mathrm{F}_{\mathrm{o}}=$ minimal fluorescence; $\mathrm{qP}=$ photochemical quenching coefficient.

observed in seedlings in the LT + DMTU group was mainly due to the addition of DMTU and the inability of the AsA-GSH cycle to function efficiently.

ROS function as signals in stressinduced anthocyanin biosynthesis (Xu et al., 2017), while anthocyanins possess significant antioxidant activity to decrease ROS contents (Silva et al., 2017). Although seedlings in the LT + DMTU group exhibited a higher $\mathrm{O}_{2}{ }^{--}$production rate than seedlings in the $\mathrm{CK}$ group (Fig. 2F), they did not display a significant up-regulation of four antho-

up-regulated (Fig. 2A-D) by both the over-accumulation of ROS (Fig. 2E-F) and the changes in the levels of AsA-GSH cycle components (Table 1); anthocyanins were eventually biosynthesized in $B$. semperflorens under LT conditions (Fig. $2 \mathrm{G}-\mathrm{H})$.

To further verify the function of LT-mediated ROS accumulation in anthocyanin biosynthesis, we analyzed the anthocyanin biosynthesis under LT conditions in the absence or presence of excess ROS in B. semperflorens.

As shown in Table 1, although seedlings in the LT + DMTU group showed higher MDHAR activity than those in the CK group, DHAR activity was the same in both groups (Fig. 3). As a result, the reduction of DHA to AsA, catalyzed by MDHAR and DHAR, was inefficient in seedlings in the LT + DMTU group. The content of AsA in seedlings in the LT + DMTU group therefore did not show a significant increase compared with CK-seedlings (Table 1). Compared with LT seedlings, the activity of APX in LT + DMTU seedlings was decreased to the same level as that in CK seedlings (Fig. 3) because of no decrease in AsA content (Table 1). Along with the chemical reduction of DHA to AsA, GSH is oxidized to GSSG, which receives $\mathrm{H}^{+}$from NADPH and is then converted to GSH by GR (Choudhury et al., 2014). Compared with seedlings in the LT group, oxidation of GSSG to GSH in the LT + DMTU group was inefficient because of the decreased NADPH content and GR activity (Fig. 3), causing an increase in GSSG content (Table 1). The result of these alterations is an imbalance in the AsA-GSH cycle, albeit with a small increase in MDHAR activity (compared with CK seedlings); the AsAGSH cycle in seedlings of LT + DMTU was no longer able to scavenge $\mathrm{H}_{2} \mathrm{O}_{2}$.

Compared with LT alone, the combination of DMTU treatment and LT significantly reduced the $\mathrm{O}_{2}{ }^{-}$production rate and $\mathrm{H}_{2} \mathrm{O}_{2}$ content in seedlings. However, the $\mathrm{O}_{2}{ }^{--}$production rate was still higher than that in CK seedlings, while $\mathrm{H}_{2} \mathrm{O}_{2}$ content was not (Fig. 2E-F). Seedlings in the LT + DMTU group exhibited higher activity of SOD (compared with CK seedlings), which converts $\mathrm{O}_{2}^{-}{ }^{-}$to $\mathrm{H}_{2} \mathrm{O}_{2}$ (de Haan et al., 1995). The enzymes APX and CAT can then detoxify $\mathrm{H}_{2} \mathrm{O}_{2}$ to $\mathrm{H}_{2} \mathrm{O}$ and $\mathrm{O}_{2}$ (Choudhury et al., 2014). The AsA-GSH cycle plays an important role in detoxifying excess $\mathrm{H}_{2} \mathrm{O}_{2}$ generated by SOD in plant cells (Choudhury et al., 2014). However, neither the activities of APX and CAT nor the contents of AsA and GSH were increased in LT + DMTU seedlings compared with CK seedlings (Fig. 3; Table 1). We therefore concluded that the detoxification of $\mathrm{H}_{2} \mathrm{O}_{2}$ under the higher $\mathrm{O}_{2}{ }^{*-}$ production rate cyanin biosynthetic genes ( $B S P A L, B s C H S, B s F 3 H$, and $B S A N S$ ) or significantly increased anthocyanin contents (Fig. $2 \mathrm{~A}-\mathrm{D}$ and $\mathrm{G}-\mathrm{H}) . \mathrm{H}_{2} \mathrm{O}_{2}$ oxidizes cysteine residues in effector proteins and is one of the most ubiquitous intracellular messengers, owing to its longevity, stability, and ability to cross biological membranes (Rhee et al., 2017; Zhou et al., 2015). Together, the results suggested that ROS was involved in LT-induced anthocyanin biosynthesis in B. semperflorens.

\section{Literature Cited}

Arrigoni, O., S. Dipierro, and G. Borraccino. 1981. Ascorbate free radical reductase, a key enzyme of the ascorbic acid system. FEBS Lett. 125:242-244.

Bradford, M.M. 1976. A rapid and sensitive method for the quantitation of microgram quantities of protein utilizing the principle of protein-dye binding. Anal. Biochem. 72:248-254.

Brennan, T. and C. Frenkel. 1977. Involvement of hydrogen peroxide in the regulation of senescence in pear. Plant Physiol. 59:411-416.

Choudhury, S., P. Panda, L. Sahoo, and S.K. Panda. 2014. Reactive oxygen species signaling in plants under abiotic stress. Plant Signal. Behav. 8:e23681.

Dalton, D.A., S.A. Russell, F.J. Hanus, G.A. Pascoe, and H.J. Evans. 1986. Enzymatic reactions of ascorbate and glutathione that prevent peroxide damage in soybean root nodules. Proc. Natl. Acad. Sci. USA 83:3811-3815.

Das, P.K., B. Geul, S.B. Choi, S.D. Yoo, and Y.I. Park. 2014. Photosynthesis-dependent anthocyanin pigmentation in Arabidopsis. Plant Signal. Behav. 6:23-25.

de Haan, J.B., F. Cristiano, R.C. Iannello, and I. Kola. 1995. Cu/Znsuperoxide dismutase and glutathione peroxidase during aging. Biochem. Mol. Biol. Intl. 35:1281-1297.

Dixon, R. and C. Steele. 1999. Flavonoids and isoflavonoids - A gold mine for metabolic engineering. Trends Plant Sci. 4:394.

Elstner, E.F. and A. Heupel. 1976. Inhibition of nitrite formation from hydroxylammoniumchloride: A simple assay for superoxide dismutase. Anal. Biochem. 70:616-620.

Foyer, C.H. and B. Halliwell. 1976. The presence of glutathione and glutathione reductase in chloroplasts: A proposed role in ascorbic acid metabolism. Planta 133:21-25.

Gibon, Y. and F. Larher. 1997. Cycling assay for nicotinamide adenine dinucleotides: $\mathrm{NaCl}$ precipitation and ethanol solubilization of the reduced tetrazolium. Anal. Biochem. 251:153.

Gu, X., Y. Chen, Z. Gao, Y. Qiao, and X. Wang. 2015. Transcription factors and anthocyanin genes related to low-temperature tolerance in rd29A: RdreB1BI transgenic strawberry. Plant Physiol. Biochem. 89:31-43.

Hung, K.T., D.G. Cheng, Y.T. Hsu, and C.H. Kao. 2008. Abscisic acidinduced hydrogen peroxide is required for anthocyanin accumulation in leaves of rice seedlings. J. Plant Physiol. 165:1280-1287. 
Hughes, N.M., H.S. Neufeld, and K.O. Burkey. 2005. Functional role of anthocyanins in high-light winter leaves of the evergreen herb Galax urceolata. New Phytol. 168:575-587.

Kim, S., G. Hwang, S. Lee, J.Y. Zhu, I. Paik, T.T. Nguyen, J. Kim, and E. Oh. 2017. High ambient temperature represses anthocyanin biosynthesis through degradation of HY5. Front. Plant Sci. 8: 1787.

Law, M.Y., S.A. Charles, and B. Halliwell. 1983. Glutathione and ascorbic acid in spinach (Spinacia oleracea) chloroplasts. The effect of hydrogen peroxide and of paraquat. Biochem. J. 210:899.

Li, B., Y. Xia, Y. Wang, G. Qin, and S. Tian. 2017. Characterization of genes encoding key enzymes involved in anthocyanin metabolism of kiwifruit during storage period. Front. Plant Sci. 8:e29526.

Li, Y.L., Y. Liu, and J. Zhang. 2010. Advances in the research on the AsA-GSH cycle in horticultural crops. Front. Agric. China 4:84-90. Liao, Z., M. Chen, L. Guo, Y. Gong, F. Tang, X. Sun, and K. Tang. 2004. Rapid isolation of high-quality total RNA from taxus and ginkgo. Prep. Biochem. Biotechnol. 34:209-214.

Livak, K.J. and T.D. Schmittgen. 2001. Analysis of relative gene expression data using Real-Time quantitative PCR and the $2-\Delta \Delta \mathrm{CT}$ method. Methods 25:402-408.

Lo Piero, A.R. 2015. The state of the art in biosynthesis of anthocyanins and its regulation in pigmented sweet oranges [(Citrus sinensis) L. Osbeck]. J. Agr. Food Chem. 63:4031-4041.

Maruta, T., M. Noshi, M. Nakamura, S. Matsuda, M. Tamoi, T. Ishikawa, and S. Shigeoka. 2014. Ferulic acid 5-hydroxylase 1 is essential for expression of anthocyanin biosynthesis-associated genes and anthocyanin accumulation under photooxidative stress in Arabidopsis. Plant Sci. 219-220:61-68.

Mita, S., N. Murano, M. Akaike, and K. Nakamura. 1997. Mutants of Arabidopsis thaliana with pleiotropic effects on the expression of the gene for $\beta$-amylase and on the accumulation of anthocyanin that are inducible by sugars. Plant J. 11:841-851.

Nakano, Y. and K. Asada. 1981. Hydrogen peroxide is scavenged by ascorbate-specific peroxidase in spinach chloroplasts. Plant Cell Physiol. 22:867-880.

Noctor, G. and C.H. Foyer. 2016. Intracellular redox compartmentation and ROS-related communication in regulation and signaling. Plant Physiol. 171:1581-1592.

Norris, K.M., W. Okie, C.L. Yakaitis, and R. Pazdro. 2016. The anthocyanin cyanidin-3-O- $\beta$-glucoside modulates murine glutathione homeosta sis in a manner dependent on genetic background. Redox Biol. 9:254-263.

Page, M., N. Sultana, K. Paszkiewicz, H. Florance, and N. Smirnoff. 2012. The influence of ascorbate on anthocyanin accumulation during high light acclimation in Arabidopsis thaliana: Further evidence for redox control of anthocyanin synthesis. Plant Cell Environ. 35:388-404.

Pagliano, C., M. Raviolo, F. Dalla Vecchia, R. Gabbrielli, C. Gonnelli, N. Rascio, R. Barbato, and N. La Rocca. 2006. Evidence for PSII donor-side damage and photoinhibition induced by cadmium treatment on rice (Oryza sativa L.). J. Photochem. Photobiol. B 84:70-78.

Rao, M.V. and D.P. Ormrod. 1995. Ozone exposure decreases UV-B sensitivity in a UV-B sensitive flavonoid mutant of Arabidopsis. Photochem. Photobiol. 61:71-78.

Reczek, C.R. and N.S. Chandel. 2015. ROS-dependent signal transduction. Curr. Opin. Cell Biol. 33:8-13.

Rhee, S.G., H.A. Woo, and D. Kang. 2017. The role of peroxiredoxins in the transduction of $\mathrm{H}_{2} \mathrm{O}_{2}$ signals. Antioxid. Redox Signal. 28:537-557. Silva, P., S. Ferreira, and F.M. Nunes. 2017. Elderberry (Sambucus nigra L.) by-products a source of anthocyanins and antioxidant polyphenols. Ind. Crops Prod. 95:227-234.
Steyn, W., S. Wand, D. Holcroft, and G. Jacobs. 2002. Anthocyanins in vegetative tissues: A proposed unified function in photoprotection. New Phytol. 155:349-361.

Takos, A.M., F.W. Jaffe, S.R. Jacob, J. Bogs, S.P. Robinson, and A.R. Walker. 2006. Light-induced expression of a MYB gene regulates anthocyanin biosynthesis in red apples. Plant Physiol. 142:1216-1232.

Tang, Q.Y. and M.G. Feng. 2002. DPS data processing system for practical statistics Sci. Press Beijing, China.

Wingler, A. 2015. Comparison of signaling interactions determining annual and perennial plant growth in response to low temperature. Front. Plant Sci. 5:1-9.

Wu, K., J. Kim, H.J. Lee, Y.J. Jung, K.K. Kang, W. Tyagi, M. Kovach, M. Sweeney, S. McCouch, and Y.G. Cho. 2017. Functional properties of an alternative, tissue-specific promoter for rice NADPHdependent dihydroflavonol reductase. PLoS One 12:e0183722.

$\mathrm{Xu}, \mathrm{Z}$., K. Mahmood, and S.J. Rothstein. 2017. ROS induces anthocyanin production via late biosynthetic genes and anthocyanin deficiency confers the hypersensitivity to ROS-generating stresses in Arabidopsis. Plant Cell Physiol. 58:1364-1377.

Zhang, C., H. Jia, W. Wu, X. Wang, J. Fang, and C. Wang. 2015 b. Functional conservation analysis and expression modes of grape anthocyanin synthesis genes responsive to low temperature stress. Gene 574:168-177.

Zhang, J., C. Chen, D. Zhang, H. Li, P. Li, and F. Ma. 2014. Reactive oxygen species produced via plasma membrane NADPH oxidase regulate anthocyanin synthesis in apple peel. Planta 240:1023-1035.

Zhang, K.M., M.L. Guo, D. He, R.H. Wu, and Y.H. Li. 2015a. The inhibition effect and excessive carbon flux resulting from blocking anthocyanin biosynthesis under darkness in Begonia semperflorens. J. Plant Growth Regul. 35:22-30.

Zhang, K.M., Z. Li, Y. Li, Y.H. Li, D.Z. Kong, R.H. Wu, and E. Pichersky. 2013. Carbohydrate accumulation may be the proximate trigger of anthocyanin biosynthesis under autumn conditions in Begonia semperflorens. Plant Biol. 15:991-1000.

Zhang, K.M., J.W. Wang, M.L. Guo, W.L. Du, R.H. Wu, and X. Wang. 2016. Short-day signals are crucial for the induction of anthocyanin biosynthesis in Begonia semperflorens under low temperature condition. J. Plant Physiol. 204:1-7.

Zhang, Y., S. Zheng, Z. Liu, L. Wang, and Y. Bi. 2011. Both HY5 and $\mathrm{HYH}$ are necessary regulators for low temperature-induced anthocyanin accumulation in Arabidopsis seedlings. J. Plant Physiol. 168:367-374.

Zhou, J., J. Wang, X. Li, X.J. Xiao, Y.H. Zhou, K. Shi, Z. Chen, and J. Q. Yu. 2014. $\mathrm{H}_{2} \mathrm{O}_{2}$ mediates the crosstalk of brassinosteroid and abscisic acid in tomato responses to heat and oxidative stresses. J. Expt. Bot. 65:4371-4383.

Zhou, J., J. Wang, K. Shi, X.J. Xiao, Y.H. Zhou, and J.Q. Yu. 2012. Hydrogen peroxide is involved in the cold acclimation-induced chilling tolerance of tomato plants. Plant Physiol. Biochem. 60:141-149.

Zhou, J., X.J. Xiao, Y.H. Zhou, K. Shi, Z. Chen, and J.Q. Yu. 2015. $R B O H 1$-dependent $\mathrm{H}_{2} \mathrm{O}_{2}$ production and subsequent activation of MPK1/2 play an important role in acclimation-induced crosstolerance in tomato. J. Expt. Bot. 65:595-607.

Zhou, Y.H., L.F. Huang, Y.S. Du, and J.Q. Yu. 2004. Greenhouse and field cucumber genotypes use different mechanisms to protect against dark chilling. Funct. Plant Biol. 31:1215.

Zhu, H., T.J. Zhang, P. Zhang, C.L. Peng, and J.P. Schnitzler. 2016. Pigment patterns and photoprotection of anthocyanins in the young leaves of four dominant subtropical forest tree species in two successional stages under contrasting light conditions. Tree Physiol. 36:1092-1104. 
Supplemental Table 1. Gene graph and primer sequences used for RT-qPCR.

\begin{tabular}{|c|c|c|}
\hline Gene name & Description & Primers used for RT-qPCR $\left(5^{\prime} \rightarrow 3^{\prime}\right)$ \\
\hline \multirow[t]{2}{*}{ BsF3H } & Forward & CGCTATTGCTTCAGGATCAG \\
\hline & Reverse & GAATCTCCCGTTGCTGAGAT \\
\hline $\mathrm{BsCHS}$ & Forward & CAGTGGCATCAGTGGAGAAG \\
\hline \multirow[t]{2}{*}{$B S P A L$} & Forward & GACGTTTCAAGGAACAAGGC \\
\hline & Reverse & TTGGCTCTATCGGAAAGCTC \\
\hline BSANS & Forward & CCAGCTTGAGTGGGAAGATT \\
\hline \multirow[t]{2}{*}{$B s 18 s-r R N A$} & Forward & GCTACCACATCCAAGGAAGG \\
\hline & Reverse & CAATGGATCCTCGTTAAGGG \\
\hline
\end{tabular}

